\title{
Parallel Experimentation: A Basic Scheme for Dynamic Efficiency
}

\author{
David Ellerman \\ Visiting Scholar \\ University of California at Riverside \\ www.ellerman.org \\ Forthcoming in: Journal of Bioeconomics
}

\begin{abstract}
Evolutionary economics often focuses on the comparison between economic competition and the process of natural selection to select the fitter members of a given population. But that neglects the other "half" of an evolutionary process, the mechanism for the generation of new possibilities that is key to dynamic efficiency. My topic is the process of parallel experimentation which I take to be a process of multiple experiments running concurrently with some form of common goal, with some semi-isolation between the experiments, with benchmarking comparisons made between the experiments, and with the "migration" of discoveries between experiments wherever possible to ratchet up the performance of the group. The thesis is that parallel experimentation is a fundamental dynamic efficiency scheme to enhance and accelerate variation, innovation, and learning in contexts of genuine uncertainty or known ignorance. Within evolutionary biology, this type of parallel experimentation scheme was developed in Sewall Wright's shifting balance theory of evolution. It addressed the rather neglected topic of how a population on a low fitness peak might eventually be able to go "downhill" against selective pressures, traverse a valley of low fitness, and then ascend a higher fitness peak. The theme of parallel experimentation is used to recast and pull together dynamic and pluralistic theories in economics, political theory, philosophy of science, and social learning.
\end{abstract}

JEL: L20, O31

Keywords: dynamic efficiency, Schumpeter, parallel experimentation, exploitation versus exploration, shifting balance theory of evolution.

\section{Table of Contents}

Introduction

The Two Strategies

Parallel and Series Experimentation

Sewall Wright's Shifting Balance Theory of Evolution

The Basic Scheme with Major Examples

The Wright Stuff

Rivalrous Firms in the Market

The Communities of Science

Political Pluralism 
Series and Parallel Project Selection

Parallel Exploration of Ideas

Parallel Experimentation in Various Thinkers

Hayek, Polanyi, and Lindblom on Spontaneous Orders and Mutual Adjustment Burton Klein's Vision of Technology Development and Dynamic Economics

Jane Jacobs' Vision of Development Through Volatile Inter-City Trade

Donald Schön and Everett Rogers on Decentralized Social Learning

Charles Sabel's Vision of Social Learning by Parallel Experimentation

Parallel Experimentation in Development

Conclusions 


\section{Introduction}

This paper uses the notion of parallel experimentation to take a fresh approach to processes for search, discovery, innovation, and learning under conditions of genuine uncertainty. ${ }^{1}$ Evolutionary processes are based not just on selection but on a shifting balance between the two opposing forces or moments of variation and selection. In more general terms, optimization on a rugged and cloudy landscape involves not just hill-climbing (selection and exploitation) but a balance between the opposing forces of variation by exploring other hills (hill-jumping in case one was climbing a low hill) and exploitation of the potential for advancing up the given hill. Variation versus selection, or, broadly, exploration versus exploitation; these are the two moments involved in any process of search, discovery, and learning. Conceptually, it is an example of the rather ubiquitous duality between parallel and series - in this case, between parallel and series experimentation.

In the older theories, selection, hill-climbing, exploitation, and serial experimentation are the focus; variation, hill-jumping, exploration, and parallel experimentation tend to get short shrift. Theories of evolution from Darwin up to Sewall Wright focused on the process of (natural) selection without serious attention to the problem of variation. ${ }^{2}$ Conventional economics has focused on the static efficiency properties of pure competition to the neglect of dynamic efficiency based on continuous discovery and innovation. Economic models of individuals and firms are based on "convexity assumptions" (i.e., only one hill to climb) so that global optimizing behavior is equivalent to local hill-climbing. Even the development of optimization algorithms in mathematics has found its main successes (e.g., simplex algorithm) in hill-climbing routines; optimization in a rugged (multipeaked) and cloudy (only partially known) landscape is quite a different matter. Given this bias on the series side, I will focus on the parallel side in order to right the shifting balance between the two sides of this duality.

\section{The Two Strategies}

There is a mathematical theory of series-parallel duality ${ }^{3}$ but our focus is on the less formal duality between series and parallel that occurs under many different guises. The basic example to keep in mind is a search through a tree of possible paths. Then two strategies become the parallel-oriented strategy of breadth-first search versus the series-oriented strategy of depth-first search. ${ }^{4}$ Is it best to commit to a branch or hill and exploit it in depth or should one emphasize breadth by exploring many branches or hills but thus with less depth? Does a detective spend more time following up on a given suspect or searching for more suspects? Every arborist faces the choice of allowing the tree's energy to go into making more branches or of pruning off branches to force the growth along what the arborist takes to be the main branch. Branch or prune? Albert Hirschman [1970] explored the dynamics of the two strategies as exit

\footnotetext{
${ }^{1}$ In economics, genuine uncertainty (as opposed to calculable risk) has been emphasized by Knight 1965, Keynes 1936, and Shackle 1992.

${ }^{2}$ In biology proper, the Extended Synthesis (or Evo-Devo) has gone well beyond the older notion of variation as random by emphasizing the filters and constraints on the development of phenotypes long before they are acted upon by selection [see Kirschner and Gerhart 2005 or the literature summarized in Fodor and Piattelli-Palmarini 2010]. Our focus here is on variation in social, economic, and knowledge processes.

${ }^{3}$ See chapter 12 "Parallel Addition, Series-Parallel Duality, and Financial Mathematics" in Ellerman 1995.

4 "The ideas of breadth and depth are in competition throughout the whole history of combinatorial optimization." [Strang 1986, 609]
} 
(exploration: looking for other options) and voice (exploitation; commitment to given option). ${ }^{5}$ For instance, the basic choice in migration is: exit to find a better home or commit to making home better. In pre-industrial development, the two main economic strategies were the exitoriented nomadic-pastoral strategy and the commitment-oriented sedentary-agricultural strategy.

Explore to find more options or better exploit the given options? Variation (finding more possibilities) or selection (choosing best among given possibilities)? Simulated annealing is a mathematical version of the blacksmith heating iron to jar the looser atoms into new configurations (variation) and then quickly cooling it so they will settle into new lower energy configurations (selection) thus strengthening and hardening the iron.

The modern complexity sciences have shown that the trade-off between exploration and exploitation is ubiquitous.

In general, investments in options and possibilities associated with "exploration" frequently come at the expense of obtaining returns on what has already been learned, "exploitation." The two possibilities form a fundamental trade-off. [Axelrod and Cohen 1999, 44]

They present the example of the two-armed bandit problem; how to maximize the return given two slot machines of different payoffs and a fixed supply of coins. Repeated experimentation with the machine that had the highest initial payoffs would increase short-run gains but experimentation with other machines would help long-run gains by reducing the error in determining which machine is in fact better. ${ }^{6}$ In other words, exploitation will get one a little higher on the given hill, but exploration will be needed to help to determine if one is climbing the right hill in the first place. ${ }^{7}$

\section{Parallel and Series Experimentation}

Parallel experimentation is taking place when there are a number of experiments taking place simultaneously all roughly with some common goal. In a scheme for series experimentation, all the resources to be used currently would be expended on the one 'best' or most promising experiment to be performed. If it did not resolve the problem, then all the resources in the next round or phase would again be put into what the experts or authorities consider the best experiment taking into account the previous results.

We immediately see one criterion for choosing between the two types of experimental schemes. If enough is known about a domain that it can be reliably determined what is the One Best Way

\footnotetext{
${ }^{5}$ The series-parallel duality provides a conceptual framework for Hirschman's voice-exit analysis.

${ }^{6}$ The original statement of the problem [Thompson 1933] was even closer to our topic, the choice among different ways of treating an illness in a population. The greater use of one technique would tell more about its chances of effecting a cure, but the use of various techniques would give more comparative information about which might be the best technique.

${ }^{7}$ In the language of analysis of variance, the limited resources to have, say, 32 trials could be all 32 trials with one treatment, 16 each with two treatments, 8 each with four treatments, and so forth. The tradeoff is between better information about the results of a given treatment or better information about the variation in results between the treatments - more information about the given hill or more exploration of other hills.
} 
[see Kanigel 1997], then there is a prima facie case for putting one's limited resources there. By the same token, parallel experimentation arises out of the lack of such definitive knowledge. When one knows that one doesn't know the best experiment with any certitude, then there is a case for dividing one's resources between a number of promising approaches.

One might imagine a "series advocate" and a "parallel advocate" giving arguments for and against each strategy. For the series proponent, a multiplicity of experiments is wasteful duplication. Isn't it rational to put one's resources on the best option? Large prideful organizations tend to favor this reasoning. The organization's experts will decide on the best experiment or approach—otherwise the organization would appear "not to know what it's doing." ${ }^{8}$ It is safer to put one's resources on the knowledgeable choice rather than waste anything on what the authorities do not support. Scattering our resources among less-promising options will detract from our best chance of getting the breakthrough by putting all our resources on the most promising option.

Parallel experimentation is based on the opposite knowledge, the Socratic knowledge that one does not know-acknowledged ignorance. There is an old distinction between risk, where rough probabilities are known, and genuine uncertainty, where the probabilities are unknown and where one has only conflicting hunches. Parallel experimentation is based on genuine uncertainty.

The use of a parallel-path strategy for the solution of difficult development problems is standard practice in several of our outstanding industrial laboratories. It is extremely common in agricultural and medical research. And in the atomicbomb project, one of the most spectacularly successful military projects the United States has ever undertaken, the parallel-path strategy was employed. [Nelson 1961, 353]

A sober reading of the history of science and engineering shows that experts are often rather myopic; they see a few steps ahead on the usual path. But the disruptive paradigm-shifting discoveries tend to come "out of left field"—from outside the conventional framework that is the stock in trade of the experts. This sort of known-ignorance pushes for the "waste and duplication" of a parallel approach.

Indeed, development work is inherently so chancy that by the law of averages, chances of success are greatly improved if there is much duplication of effort....Just so, when Pasteur, that wise old man, begged for enlarged support of the biological sciences, he begged for multiplication of laboratories. [Jacobs 1969, 90-1]

The two strategies also emerge as the two dual strategies for reducing risks. When one has little knowledge or control over which basket will get spilled, then diversification is the best

\footnotetext{
${ }^{8}$ Note how the series advocate mixes theoretical and organizational arguments-which is how these issues arise in practice.
} 
strategy-spread one's eggs between many baskets. But if one can by a concentration of scarce resources better control some baskets, then the best strategy may be to "put all one's eggs in just a few baskets and carefully control them." These two strategies for reducing risks correspond to the two biological reproductive strategies designed to reduce the risk that parents will leave no offspring to reproduce again. Where parents have little or no control over the chances of the offspring to survive, then they use their energy to produce a large number of offspring like many insects or fish-"they distribute their eggs into many baskets"—-which is called the "r selection" strategy. If parents can control their environment well, then they can concentrate their energies in a few offspring as with mammals - "put their eggs in a few baskets and carefully control them"-which is called the "K selection" strategy. ${ }^{9}$ In reliability theory where all components or elements of a unit need to work in order for the unit to work (i.e., a series connection) and if one can improve the reliability of the individual components, then there are the two strategies of increasing reliability: by increasing redundancy (parallelism) of units or improving the components in a unit. ${ }^{10}$

Organized experimentation requires some organized method of evaluation of the experiments. There are two dual strategies of evaluation corresponding to the experimental strategies. Series evaluation compares the results with the previous results in serial experimentation. Often the sequential experiments would lead to improvements over previous results so an organization's evaluation can point with pride at the outcomes. "Our performance is an improvement over last year." For a forward-looking organization, an evaluation might also focus on what on what can be learned to further improve the results. It is a safe and sane procedure for organizations to secure steady progress along what they have already decided is the right path.

In parallel experimentation, a quite different type of evaluation is possible, namely the sideways benchmarking comparisons with the outcomes of the other parallel experiments-as is common in experimental design to test different treatments. It is perhaps serendipity that the parallel scheme has this built-in type of evaluation since parallel experimentation would tend to be used precisely when there is a dearth of experts or prior experience to decide on the "best treatment." It is a "bootstrapping" type of evaluation.

Before turning to the main example from biology, it might be useful to summarize the examples of the series-oriented and parallel-oriented strategies.

\begin{tabular}{|l|l|l|}
\hline Table 1:The Two Strategies & \multicolumn{1}{|c|}{ Series-focused Strategy } & \multicolumn{1}{|c|}{ Parallel-focused Strategy } \\
\hline Evolution & $\begin{array}{l}\text { Selection of fittest among } \\
\text { given possibilities }\end{array}$ & $\begin{array}{l}\text { Variation to generate more } \\
\text { possibilities }\end{array}$ \\
\hline $\begin{array}{l}\text { Optimization on rugged } \\
\text { cloudy landscape }\end{array}$ & $\begin{array}{l}\text { Climbing the hill you are on } \\
\text { (commit rather than switch) }\end{array}$ & $\begin{array}{l}\text { Jumping to other hills (switch } \\
\text { rather than commit) }\end{array}$ \\
\hline Genetic algorithms & Exploit & Explore \\
\hline Experimentation & $\begin{array}{l}\text { Series experiments each } \\
\text { putting most resources into } \\
\text { the One Best Way }\end{array}$ & $\begin{array}{l}\text { Parallel experiments putting } \\
\text { some resources on a number } \\
\text { of promising ways }\end{array}$ \\
\hline
\end{tabular}

\footnotetext{
${ }^{9}$ See biology texts such as Wallace et al. 1991, 1206.

${ }^{10}$ For instance, see the section entitled "Redundancy versus improved elements" [Von Alven 1964, 240].
} 


\begin{tabular}{|l|l|l|}
\hline Table 1:The Two Strategies & \multicolumn{1}{|c|}{ Series-focused Strategy } & \multicolumn{1}{|c|}{ Parallel-focused Strategy } \\
\hline Evaluation & $\begin{array}{l}\text { Compare to previous results } \\
\text { in sequential experiments. }\end{array}$ & $\begin{array}{l}\text { Compare to current results in } \\
\text { simultaneous experiments. }\end{array}$ \\
\hline Simulated annealing & $\begin{array}{l}\text { Cooling (to settle into nearby } \\
\text { low energy configurations) }\end{array}$ & $\begin{array}{l}\text { Heating (to generate a new set } \\
\text { of possible configurations) }\end{array}$ \\
\hline Searching a tree & Depth-first search & Breadth-first search \\
\hline Growing a tree & Pruning & Branching \\
\hline Hirschmanian dynamics & $\begin{array}{l}\text { Voice: use voice to make the } \\
\text { given option better. }\end{array}$ & $\begin{array}{l}\text { Exit: use exit to find a better } \\
\text { option. }\end{array}$ \\
\hline $\begin{array}{l}\text { Pre-industrial Economic } \\
\text { Strategies }\end{array}$ & Sedentary-agriculturalist & Nomadic-pastoralist \\
\hline Risk reduction & $\begin{array}{l}\text { Put your eggs in a few baskets } \\
\text { and control them carefully. }\end{array}$ & $\begin{array}{l}\text { Spread your eggs between } \\
\text { many baskets }\end{array}$ \\
\hline Reproductive strategies & $\begin{array}{l}\text { K selection: put resources in a } \\
\text { few offspring and take care of } \\
\text { them. }\end{array}$ & $\begin{array}{l}\text { r selection: put resources into } \\
\text { many offspring with little or } \\
\text { no care to each. }\end{array}$ \\
\hline Reliability Theory & $\begin{array}{l}\text { Increase reliability of system } \\
\text { components. }\end{array}$ & $\begin{array}{l}\text { Increase redundancy } \\
\text { (parallelism) in system. }\end{array}$ \\
\hline
\end{tabular}

\section{Sewall Wright's Shifting Balance Theory of Evolution}

Evolutionary change involves the interplay between two processes: variation and selection. Variation expands the range of possibilities and selection narrows it. Charles Darwin's theory of evolution was a theory about selection, the theory of natural selection. Darwin and Darwinism have had relatively little to say about the structure of variation aside from the fundamental nonLamarckian point that variation is "blind" in the sense of being independent of learning during the lifetime of an organism. Today, evolutionary — or, to be more precise, selectionist—-theories abound. In addition to biological evolution, there are selectionist theories of pre-life molecular evolution [Eigen 1992], selectionist theories of the immune system [e.g., Jerne 1955; Burnet 1959] and the brain [Edelman 1987], and even an evolutionary theory of epistemology [Popper 1965, 1979; Campbell 1974]. Some have made rather universal claims for "Darwin's dangerous idea" [Dawkins 1983; Dennett 1995; Cziko 1995]. Universal Darwinism has largely meant Universal Selectionism.

Following Thorstein Veblen famous question, "Why is economics not an evolutionary science?" [1919], Joseph Schumpeter [1934], Friedrich Hayek [1988], Richard Nelson and Sidney Winter [1982], Stanley Metcalfe [2001], and many others have developed evolutionary approaches to economics (see Nelson 1995, Hodgson 1996, and the special issue of the Journal for Evolutionary Economics edited by Witt 2006). Through all this explosion of evolutionary theories, the emphasis has been on the selection mechanism (hill-climbing)—not on the process of variation (hill-jumping). The argument made here is that focusing on parallel experimentation and the problem of variation, principally in Sewall Wright's shifting balance theory of evolution, will help to remap the correspondence between the processes of biological and economic evolution. 
Sewall Wright (1889-1988) together with Ronald A. Fisher and J. B. S. Haldane were the three progenitors of one of the revolutions in modern biology, the mathematical theory of population genetics [see Provine 1971]. In the recent complexity science literature, Wright is more often mentioned as the inventor of the "fitness landscape" to represent optimization on a very rugged and cloudy landscape. Yet the fitness landscape was only a tool Wright used to expound his shifting balance theory of evolution. ${ }^{11}$

Natural selection is a mechanism to push a population up a fitness hill-but it may be a very low hill. "The problem of evolution as I see it is that of a mechanism by which the species may continually find its way from lower to higher peaks in such a field." [Wright 1932; reprinted in Wright 1986, 163-4] How does evolution ever get the population back down a hill and across a valley of low fitness to climb a much higher hill? If selection operates to cut down variety to the survival of the fittest, what is the mechanism to increase variety in order to find a path from low to higher hills? Many biologists, Fisher and Haldane among them, don't think any special theory is required. They had faith that the variety introduced in the whole population by mutation, sexual reproduction, genetic drift, and other changes in the environment will suffice. ${ }^{12}$ Sewall Wright was not satisfied with that explanation.

Like Darwin, Wright thought it relevant to carefully observe artificial selection. Wright found that breeders do not keep all their animals together in one interbreeding herd. They deliberately break the herd up into subherds, subpopulations, "races," or 'demes' (as in demography). It is a question of balance. The subherds should be small enough so that the variety found in the subherd (through sampling error) or created through mutation, sexual reproduction, and genetic drift will be emphasized through inbreeding. But the subherd should not be so small that inbreeding leads to the quick fixation of ill-adapted genes and the deterioration or demise of the subherd. When a clearly superior example is produced in a subherd, then the seed is crossbred into the other subherds to give them the benefit of the innovation. But seeds could not be constantly crossbred between the subherds as that would defeat the benefits of their semiisolation. Shifting balances were involved. How small to make the subherds and how much cross-breeding between the subherds?

Seeing these processes at work in artificial breeding and selection, Wright reasoned that Nature might have found some version of parallel experimentation with naturally forming subpopulations and cross-fertilization by migration.

Judging from animal breeding, [Wright] thought that natural populations must be subdivided into small-enough partially isolated subgroups to cause random drifting of genes but large-enough subgroups to keep random drifting from

\footnotetext{
11 The main papers from the 1930s are collected together in Wright 1986.

12 The simple contrast of hill-climbing and hill-jumping ignores possible higher order effects that deform the fitness landscape. The much-studied effects of lock-in [David 1985] after climbing a sub-optimal hill could be seen as deforming the landscape to make hill-jumping even more difficult. Along similar lines is the whole literature on increasing returns and positive feedback process starting with Young 1928--not to mention Adam Smith's treatment of pin-making. In writings too little known in economics, Jane Jacobs [1969] has noted that real innovation beyond a locked-in highly specialized process like Smith's pin-making does not come from further hill-climbing but from a hill-jump prompted by technological developments elsewhere. Hence the importance of the near-by technological diversity provided by a city.
} 
leading directly to fixation of genes, for this was the road to degeneration and extinction. Mass selection within subgroups was followed by selective diffusion from subgroups with successful genetic combinations. The final step was the transformation of all subgroups by the immigration of organisms with a superior genotype and subsequent crossbreeding. [Provine 1986, 236]

The point is that by dividing the population into demes, there is more variation and exploration. Since the results can be reaped by the whole population through crossbreeding, the overall rate of advance is increased.

The average adaptiveness of the species thus advances under intergroup selection, an enormously more effective process than intragroup selection. The conclusion is that subdivision of a species into local races provides the most effective mechanism for trial and error in the field of gene combinations. [Wright 1932; reprinted in Wright 1986, 168]

The implicit rivalry or competition between demes is not to be confused with the competition between individuals within each deme and within the main population. The "parallelism" in the shifting balance theory is the parallel experimentation of the different demes or subpopulations, i.e., different hills in the fitness landscape.

The similarity between this evolutionary scheme and parallel experimentation to generate and share good ideas is not lost on biologists. Richard Dawkins illustrates evolution with a computerized model of spiders evolving with fitness determined by the fly-catching properties of their various webs. ${ }^{13}$ The spiders are divided into "three 'demes' evolving in parallel."

These were thought of as evolving independently in three different geographical areas. But-here's the point—not completely independently. There is a trickle of genes, meaning that an individual occasionally migrates, from one local population to another. The way I put it was that these migrant genes were a kind of injection of fresh 'ideas' from another population: 'almost as though a successful sub-population sends out genes that "suggest" to a less successful population a better way to solve the problem of building a web'. [Dawkins 1996, 136]

The smallness of the sub-populations plays a role in promoting greater variety in the experiments. This boils down to the mathematical fact that the smaller the number of independent random variables added together, the greater the 'random walk' in the sum of the variables. This fact has a marvelous illustration.

This is the same principle that prevents a large herd of horses that are tethered together from moving any great distance in a finite time, whereas, as any cowboy

\footnotetext{
${ }^{13}$ See Tanese 1989 for an early use of Sewall Wright's idea of sub-populations in computerized genetic algorithms.
} 
knew, a small band of horses tied together for the night could easily be out of sight by sunrise. [David and Foray 1994, 72]

Of course, the outcomes of human experiments are not just random variables but a similar principle seems to hold, namely that there is more creativity in small than large groups. Thus systems will show more 'out-of-sight' creativity and dynamic development with coordinated parallel experiments carried out by small groups (with systematic diffusion of successes between the groups ratcheting up the whole group) than with experimentation in one large group.

\section{The Basic Scheme with Major Examples The Wright Stuff}

From the shifting balance theory and other examples, we might tentatively outline a general scheme ("the Wright stuff") for experimentation and learning in the context of uncertainty and known ignorance:

- different experiments ("demes") running concurrently with some common goal,

- with some semi-isolation from immediate competitive pressures,

- with benchmarking comparisons made between the experiments, and

- with the "migration" of discoveries between experiments wherever possible to ratchet up the performance of the whole population.

\section{Rivalrous Firms in the Market}

Perhaps the best example is that of a rivalrous market. But the notion of "pure competition" captured in economic theory is a competition of near-clones (e.g., small farmers all producing the same homogenous crop) which leaves out the crucial element of variation (different parallel experiments). Furthermore the notion of semi-isolation or semi-autonomy of the firms (which allows the introduction of variety) is absent from the crude notions of "competition" and "survival of the fittest" found in much of the literature. The static market process drives toward a local optimality (any change would be downhill in terms of someone's preferences) just as a selection-oriented hill-climbing notion of evolution would lead to perfect adaptation at the top of whatever hill in the fitness landscape the population occupied. Both notions were well-suited for a single-peaked landscape.

The parallel experimentation scheme occurs in the Schumpeterian [1934, 1962] rivalry of medium-to-large firms (the "demes") that take different approaches and that threaten to take away market share from each other. The scheme that Wright saw as the most effective way to advance genetic adaptation in a multi-peaked landscape translates into an economic notion of dynamic efficiency in a complex and changing world.

Benchmarking between firms provides the best real-time measure of how a firm is doing. A firm can depend on some rivals to innovate so, like the Red Queen, it has to innovate as well just to keep up. When innovations are made, then the rivals have to figure out how to license, work around, or otherwise assimilate the new ideas. This "cross-breeding of a new gene" back into the other "subherds" to lift the performance of all is limited by the degree and nature of intellectual property protection. 
"Scientific socialism" used series-oriented reasoning to provide a "rational" alternative to the "irrational" duplication and waste of rivalrous firms. Engineers and consumer experts could agree on the current best product for a certain use. Then the returns to scale of modern manufacturing could be fully exploited to mass produce that product. In the meantime, researchers would be devising and testing ways to make still further improvements so that the One Best Product would get even better.

\section{The Communities of Science}

Perhaps the purest example of parallel experimentation as a scheme for collective innovation and learning is provided by the communities of scientific researchers working in a field. They also work in small semi-independent groups who constantly face the same shifting balance decisions about working in bigger or smaller groups, or closely following what others are doing versus striking off in new directions. Innovations are quickly transmitted via the scientific literature to the other groups for intersubjective verification and cross-learning. The knowledge available to all the groups is ratcheted up.

The series advocate would again like to use "what we know" to cut down on the wasteful exploration of discredited ideas. The experts should be able to broadly agree on the best path of research and then centrally controlled resources should allocated along that path. Perhaps the most famous example in recent history in the life sciences was the Soviet experts' decision that Lysenkoism represented the path for Soviet genetics to take. The other branches on the tree could be pruned away.

\section{Political Pluralism}

A third major example is the pluralism of political parties or organizations (e.g., cities or states in a federation) taking different positions and performing different experiments addressing common social problems. The rivalry between political parties is immediate and direct while the rivalry between diverse cities or states is more indirect. But in all cases, the idea is to have within the whole polity a number of positions being articulated and a number of parallel experiments going on with some form of benchmarking and cross-learning so that innovations will serve to ratchet up performance across the polity.

Here again, the series advocate is well-represented by communism. When one has access to the "science" of the "innermost workings of history" then parallel experimentation is only a waste of resources promoted by those who do not appreciate the "levers of social change." With "scientific socialism" now in the dustbin of history, the spirit of the "scientific" organization and control of society lives on in the "application" of orthodox economics as represented, for instance, by the International Monetary Fund and the World Bank promoting the "Washington consensus." ${ }^{14}$ But antipathy to parallel experimentation comes not only out of ideologies which already know "the Path"; it comes even more often from authoritarian regimes or organizations who have no interest in sponsoring a genuine alternative. It may be a low hill but they are on top of it and any parallel experimentation would be downhill for them.

\footnotetext{
${ }^{14}$ See Chang 2001, Stiglitz 2002, and Ellerman 2002.
} 


\section{Series and Parallel Project Selection}

Many of the points about series and parallel experimentation appear in a slightly different guise in the contrast between series and parallel project selection. ${ }^{15}$ With series selection, a project has to jump over a series of hurdles. Rejection by any one of the evaluators means rejection of the project. But in parallel selection, a project can be submitted to a number of evaluators. The project is selected if it passes any one of them. If it fails to be selected by one party, the project can be resubmitted for a second chance with another party.

Parallel selection is essentially parallel experimentation from the viewpoint of a project or an idea. If multiple parties are carrying out experiments, then we could think of a project or idea going from party to party to try to be accepted or "discovered." But with series experimentation, the project or idea only has one chance to eventually emerge as being accepted or discovered as the series of experiments go on.

Let us now suppose two kinds of projects or ideas, good and bad, where good projects should be accepted and bad ones rejected. But the characteristics are hidden. Then there are two types of error: type I error of rejecting a good project and type II error of accepting a bad project. Assume the evaluators (strung in series in the one case and spread out in parallel in the other) have a certain probability of accepting a good project and a probability of rejecting a bad project. "Two results immediately emerge: polyarchical organizations [parallel selection] accept more bad projects...; while hierarchical organizations [series selection] reject more good projects...." [Sah and Stiglitz 1985, 293] Of course, it best to avoid both types of error but eventually the design of a selection mechanism will have to trade off one error for another. Series selection tends to commit type I error, rejecting some good projects but rarely letting a bad project pass. Parallel selection favors the opposite sin of type II error, accepting some bad projects but rarely rejecting a good project. Although individual decision-making centers might reject a good project, the overall system of having many second chances would make it very rare for a good project to be rejected overall.

The losses and gains will depend on the nature of the projects. If a bad project would release into the air a biological pathogen that would cause great damage, then one would prefer a decision-making mechanism that would error on the side of caution, i.e., avoid type II errors ("like the plague") and be more tolerant of type I errors. This is the reasoning behind the "precautionary principle" advocated by some environmentalists. For these situations, the popular wisdom is "Better safe than sorry" or "The better part of valor is discretion." This could be implemented by having series project selection, a single channel with multiple stages each of which would have to accept the project in order for it to pass.

But the projects faced by economic enterprises are usually of a different sort; when a bad project is selected then only some time, energy, and economic resources are wasted. Failure is not fatal; indeed some economic institutions such as the limited liability company and social safety nets are designed to take some of the "sting" out of the death of a project. In these situations, the popular wisdom is "Nothing ventured, nothing gained" or "Better to have tried and failed than not to have tried at all." Richard Tawney indicated a preference for type II errors when he

\footnotetext{
${ }^{15}$ See the work of Raaj Sah and Joseph Stiglitz [1985] summarized in Stiglitz [1994]
} 
asserted that "rashness is a more agreeable failing than cowardice" [1954, 235]. This would be implemented by the dual arrangement of parallel project selection, multiple decision centers where acceptance by any one is sufficient for the project to pass.

Better is the approach of companies such as Ore-Ida, the potato processor, which has given many different people, designated "Ore-Ida fellows," the ability to seed innovations with grants. In this way, different vicarious selection systems run in parallel, providing more than one means for variations to propagate. [Anderson 1999, 139]

Now contrast a society with parallel experimentation such as Renaissance Europe which had competing centers of power, and centralized China at the same time (Ming Dynasty). Take the viewpoint of a project, such as Columbus' project. The political fragmentation of Europe gave it more of a chance than the centralized structure of China. Columbus was turned down by the King of Portugal and two Spanish dukes before submitting his proposal to Ferdinand and Isabella who finally accepted it in 1492. In China, Columbus would not have had a second chance. ${ }^{16}$

With centralized or monopoly project selection, there is no fear that a rejected innovation will be adopted by a competitor while an accepted innovation might have an uncertain effect on the monopoly. Thus hierarchical centralization has been a recipe for uniform and essentially static societies from Ancient Egypt to the Soviet Union characterized by more "discretion" or "cowardice" (type I error). By the same token, in a market economy, the multiplicity of parallel decision-making centers means more "rashness" (type II error).

Western economies authorize a large number of enterprises, as well as individuals who might form new enterprises, to make decisions to accept or reject proposals for innovation, their own or others'. The rejection of a meritorious proposal by a half-dozen decision-making centers is presumably less probable than its rejection by only one. The system is thus biased toward the acceptance of proposals,... [Rosenberg and Birdzell 1986, 258].

Developing and transitional countries are weighted down with the inertia of the past. Political, religious, and customary authorities may see any real change as the potential release of a "pathogen" so they tilt toward type I error and stasis. Series experimentation tends to be the rule where there is a central authority that seeks to improve its position but will not tolerate disruptions from other parallel experiments. Only the center experiments; the periphery implements. Otherwise, the center would be giving up power to the periphery to find a different future.

A grant of that kind of freedom costs a society's rulers their feeling of control, as if they were conceding to others the power to determine the society's future. The

\footnotetext{
16 "European-style wars between internal political units became rare in China after 960 A.D. The absence of political competition did not mean that technological progress could not take place, but it did mean that one decision maker could deal it a mortal blow." [Mokyr 1990, 231] In comparing Ancient China and Europe, Joseph Needham noted a tendency towards "homeostasis" in Chinese society while Europe exhibited a "built-in quality of instability" [1969, 119].
} 
great majority of societies, past and present, have not allowed it. Nor have they escaped from poverty. [Rosenberg and Birdzell 1986, 34]

In one context after another, it is the resistance of those in power to make a "grant of that kind of freedom" that impedes the more frequent use of parallel experimentation.

\section{Parallel Exploration of Ideas}

Parallel experimentation in science is only the purest example of a much broader liberal argument for the diversity and contestation of ideas. It is extraordinarily difficult to hold two or more competing ideas or theories in suspension while at the same time caring which one is true or would be best for the case at hand. In The Crack-up, F. Scott Fitzgerald famously noted that the "test of a first-rate intelligence is the ability to hold two opposed ideas in the mind at the same time, and still retain the ability to function." John Dewey emphasized that scientific inquiry involves:

willingness to hold belief in suspense, ability to doubt until evidence is obtained; willingness to go where evidence points instead of putting first a personally preferred conclusion; ability to hold ideas in solution and use them as hypotheses to be tested instead of as dogmas to be asserted; and (possibly the most distinctive of all) enjoyment of new fields of inquiry and of new problems. [Dewey 1039, 145]

Carl Sagan recommends parallel exploration not only for science but for anyone who wishes to think critically and skeptically; it is part of the "fine art of baloney detection."

Spin more than one hypothesis. If there's something to be explained, think of all the different ways in which it could be explained. Then think of tests by which you might systematically disprove each of the alternatives. What survives, the hypothesis that resists disproof in this Darwinian selection among "multiple working hypotheses," has a much better chance of being the right answer than if you had simply run with the first idea that caught your fancy. [Sagan 1996, 210]

The rush to judgment based on prejudice (premature convergence and lock-in in a search) is the sin for which the parallel exploration of idea or theories is the penitence. ${ }^{17}$ "Baconian idols of the tribe, the cave, the theater, and den have caused men to rush to conclusions, and then to use all their powers to defend from criticism and change the conclusions arrived at." [Dewey 1939, 146] This is such a strong tendency that various organizational innovations are needed to address the problem.

\footnotetext{
${ }^{17}$ Hirschman used Flaubert's "La Rage de Vouloir Conclure" [Hirschman 1973, 238] to describe this rage to conclude.
} 
The basic idea of the parallel exploration of ideas is usually expressed as competition in the marketplace for ideas ${ }^{18}$ — "the proposition that truth naturally overcomes falsehood when they are allowed to compete.... The belief that competing voices produce superior conclusions [is]... implicit in scientific reasoning, the practice of trial by jury, and the process of legislative debate." [Smith 1988, 31]

Within organizations, the idea might be implemented with some form of organized opposition or devil's advocacy. ${ }^{19}$ When considering someone for sainthood, the Roman Catholic Church has a "devil's advocate" (Advocatus Diaboli) to state the other side of the story. The defendant's right to an attorney in a courtroom has a similar role; it takes away from the prosecutor the monopoly right to present evidence and arguments. A judge may not go to the jury before both sides of the arguments have been heard, and a patient should not go to surgery before getting a second opinion.

Devil's advocacy [see Schwenk 1984] is also interpreted broadly to include a number of related techniques to better elicit the main alternatives in a decision. A Cassandra's advocate [Janis 1972, 217] is a person who emphasizes alternative interpretations of data and focuses on all the things that can go wrong ("Murphy's Law-yer"). The Rashomon effect [see Schön 1971, 210] illustrates that the same set of circumstances and events can be interpreted very differently by different people. Discussion organized as a debate between the proposed policy and the best alternative has been called the dialectical method [see Schwenk 1989]. Multiple advocacy [Haas 1990, 210], equivocality [Weick 1979, 174], and double visioning [see Schön 1983, 281] refer to the practice of not only allowing but fostering the presentation of two or more options.

The political scientist Alfred De Grazia recommends a countervailance system as a part of any large bureaucracy. "The countervailors would be a corps of professional critics of all aspects of bureaucracy who would be assigned by the representative council of an institution to specialize as critic of all the subinstitutions." [168, 1975] The devil's advocacy concept can also be applied to written documents. When Jefferson complained about the one-sided press, James Madison half-seriously asked: "Could it be so arranged that every newspaper when printed on one side, should be handed over to the press of an adversary, to be printed on the other, thus presenting to every reader both sides of every question, [so] truth would always have a fair chance." [quoted in Smith 1988, 41] Perhaps the op-ed page in a newspaper could be seen in this light.

Another example is the systematic inclusion of dissenting opinions in higher court decisions made by a panel of judges. The concept could be applied widely to written reports recommending a specific policy or course of action. A well-constructed options paper will not just argue the virtues of the preferred option but will present the best alternatives - or better yet have those alternatives be presented by their advocates. Conference volumes often present the main papers along with written comments and criticism by the discussants. Some journals [e.g., The Behavioral and Brain Sciences and The Journal of Economic Perspectives] are organized in

\footnotetext{
${ }^{18}$ John Milton expressed the idea in his defense of intellectual freedom in Areopagitica. "And though all the winds of doctrine were let loose to play upon the earth, so Truth be in the field, we do injuriously, by licensing and prohibiting, to misdoubt her strength. Let her and Falsehood grapple; who ever knew Truth put to the worse, in a free and open encounter?" It is a point that still needs to be argued, e.g., Sunstein 2003.

${ }^{19}$ See Lipset et al. 1962 or Ellerman 1988.
} 
the powerful and rewarding format of invited papers followed by criticism, commentary, and counter-articles all in the same issue. The Opposing Viewpoints Series of Greenhaven Press is a book series that focuses on giving point and counter-point on the major issues [e.g., Rohr 1989]. The preface in each volume cites John Stuart Mill in On Liberty:

The only way in which a human being can make some approach to knowing the whole of a subject, is by hearing what can be said about it by persons of every variety of opinion, and studying all modes in which it can be looked at by every character of mind. No wise man ever acquired his wisdom in any mode but this. (quoted in preface to: Rohr 1989, 10)

Mill argued that even in cases of settled opinions, debate and discussion serve to disturb the "deep slumber of a decided opinion" so that it might be held more as a rational conviction rather than as an article of faith.

So essential is this discipline to a real understanding of moral and human subjects, that if opponents of all important truths do not exist, it is indispensable to imagine them, and supply them with the strongest arguments which the most skillful devil's advocate can conjure up. [Mill 1972, 105]

This also relates to the theme of democracy as being based on government by discussion.

The traditional theory of the contest and interplay of group interests was not so much a scientific description as a normative injunction; in fact it contained the moral basis of liberal democracy. In order for the truth to be known, this theory argued, speech must be free; in order for wise decisions to be made, all the interests must be in the field and all the values articulated. [Matson 1966, 107]

The same themes about the competition and parallel exploration of ideas help to explain the uniqueness of Ancient Greece. The penchant for competition was one of the key features of Ancient Greece ${ }^{20}$ that distinguished it from other societies of antiquity, and Socrates represented the use of dialogue and contestation as the road to improving knowledge. "The form Socrates' teaching took - intellectual dueling before a sportive audience-looks much odder to us than it did to Athenians, whose whole culture was based on the contest (agōn), formal and informal, physical, intellectual, and legal." [Wills 1994, 163] Even drama had the leading contestant (protagonist) and the opposing contestant (antagonist).

Geoffrey Lloyd [1996] has used the idea of contestation to address the question of why, after such a promising beginning in ancient China, science developed strongly in ancient Greece but not in China. The key feature in ancient China was the intermixing of power with questions of empirical truth — a feature shared with the role of the Church in the Middle Ages or with Lysenkoism (and the role of the Party in general) in the Soviet Union. The Emperor's Mandate of Heaven was based on a view of the world that pictured the Emperor in the central role of

\footnotetext{
${ }^{20}$ The locus classicus for this emphasis on contestation in Greek civilization is Burckhardt [1998 (1898)].
} 
maintaining the harmony between Heaven and Earth. The views of philosophers and scientists needed to accommodate that basic scheme. In contrast, the Greek intellectual life exhibited "radical revisability" [Lloyd 1996, 216] where the masters would offer theories completely at odds with those of their rivals - a practice that would not be allowed where the Mandate of Heaven was seen as being based on the Official Theory. Chinese intellectual life put the emphasis on accommodation and harmony while the Greeks thrived on antagonism and adversariality. The differences extended throughout social and legal affairs.

Differences between individuals or groups that might well have been the subject of appeal to litigation in Greece were generally settled [in China] by discussion, by arbitration, or by the decision of the responsible officials. The Chinese had, to be sure, no experience that remotely resembled that of the Greek dicasts [large public juries], nor, come to that, that of Greek public participation in open debate of political issues in the Assemblies. [Lloyd 1996, 109]

\section{Parallel Experimentation in Various Thinkers \\ Hayek, Polanyi, and Lindblom on Spontaneous Orders and Mutual Adjustment}

Friedrich Hayek [see "Competition as a Discovery Procedure" in 1984], Michael Polanyi [1951; 1966], and Charles Lindblom [1965; 1990] have all emphasized some of the similarities between markets, science, and democratic pluralism as spontaneous orders showing various degrees of mutual adjustment without central direction. All have criticized the hubris of "synoptic" knowledge that often lies behind centralized series experimentation. Parallel experimentation schemes are often supported by the acknowledged ignorance of that type of knowledge. And all three have emphasized the multitude of parallel agents who coordinate with and learn from each other without central direction. ${ }^{21}$

These conceptions of a spontaneous orders are, however, somewhat broader than the sharper notion of parallel experimentation. In terms of the biological root metaphor, the parallel experimenting subpopulations are of the same species. Thus the competitive rivalry of firms taking different approaches in the same business would be a parallel experimentation scheme while all the interactions of producers and consumers are subsumed into the broader notion of the market as a spontaneous order. In science, it is rivalry and cooperation of groups working on the same general problem — a "society of explorers" [Polanyi 1966] — that is parallel experimentation while the conception of "science" as a spontaneous order is much broader. Within a multi-party system, the parties might compete to present solutions to common problems to the voters. Within a federation of states, the states might function as political laboratories to each try to find solutions to common vexing problems. The states might be more inclined to cross-breed solutions than parties, but in both cases there would be some implicit or explicit cross-learning from the parallel efforts. But, again, the idea of the political system as a system of mutual adjustment is much broader. Thus I only wish to record the idea of parallel experimentation as a part of their broader conceptions of the market, science, and a "self-guiding society" [Lindblom 1990].

\footnotetext{
${ }^{21}$ The development of the Linux operating system [see Axelrod and Cohen 1999] by the coordinated effort of thousands of programmers provides a modern example of what can be produced in a spontaneous order or "bazaar" rather than a "cathedral" [see Raymond 1998].
} 


\section{Burton Klein's Vision of Technology Development and Dynamic Economics}

Albert Hirschman shared with Charles Lindblom the skepticism about the synoptic or comprehensive knowledge assumed by state planners. Hirschman [1958] used to criticize the idea of a state-coordinated "big push" toward balanced growth in a developing country. Hirschman proposed an alternative approach which he called "unbalanced growth." The idea was to work with and try to catalyze the endogenous economic and political pressures that arise from both bottlenecks and sudden openings to galvanize scattered energies to make structural changes.

The similarities between Hirschman and Lindblom lead to them writing a joint paper [1971] which also discussed the work of Burton Klein. In an early work on technology development, Burton Klein writing together with William Meckling [1958] contrasted dynamic technology development strategies with the usual Olympian or "synoptic" approach of operations research. In the usual approach, the analyst, Mr. Optimizer, would gather the best current views, perhaps a consensus of the experts, as to what was the best option and then plans would be drawn to rationally allocate resources to develop that option-much like a development program based on the Official Views determined by the consensus of experts at elite development agencies. This is the strategy of series experimentation.

Klein and Meckling proposed an alternative approach of Mr. Skeptic, parallel experimental development of several main options with early prototyping to "see what works" and then let later allocation decisions be guided by the results of these experiments.

They [Klein and Meckling] allege that development is both less costly and more speedy when marked by duplication, "confusion," and lack of communication among people working along parallel lines. Perhaps more fundamentally, they are against too strenuous attempts at integrating various subsystems into a wellarticulated, harmonious, general system; they rather advocate the full exploitation of fruitful ideas regardless of the "fit" to some preconceived pattern of specifications. [Hirschman and Lindblom 1971, 66-7]

Note the critique of the over-planning according to initial preconceptions. Klein and Meckling see the problem as "not one of choosing among specific end-product alternatives, but rather a problem of choosing a course of action initially consistent with a wide range of such alternatives; and of narrowing the choice as development proceeds." [1958, 352] This is a recurring theme in the parallel experimentation literature.

In his later work, Klein developed his earlier analysis of parallel technology development projects in the presence of genuine uncertainty into a full-fledged vision of dynamic economics [1977; 1984]. Klein like many others wanted to develop Schumpeter's vision of a truly dynamic economy driven by entrepreneurial energies to continuously innovate and to create a perennial gale of creative destruction. Klein focused on rivalry between firms threatening each other's market shares as the driving force of dynamics. 
A recurring theme in parallel experimentation is the de-emphasis on static efficiency in favor of a dynamic efficiency characterized by continuing problem-solving and improvement. ${ }^{22}$ In a dynamic setting, variation- and innovation-related characteristics such as flexibility, versatility, diversification, and resilience gain in importance. Static efficiency, e.g., through minute division of labor, may be perfect adaptation to the old environment but in a changing environment, it may turn out to be premature convergence and over-adaptation. ${ }^{23}$

When one firm might operate in text-book fashion by carefully optimizing its products for the market at particular points in time, another might never engage in such a seemingly rational strategy, yet, in five or ten years time will completely outdistance the first firm....In all disciplines, dynamic considerations were brought into play by trying to understand phenomena which did not agree with a static paradigm. Biologists, for example, found that characteristics which permitted species to adapt to a given environment were by no means the same as those required for survival in a rapidly changing environment. [Klein 1984, 199] ${ }^{24}$

Returning to the biological root metaphor, the de-emphasis on static efficiency is also seen in the idea of semi-isolation from the fitness pressures "in a larger population" in order to "pass through a 'valley' of reduced fitness" to then climb a higher peak elsewhere. Similarly within large firms, they can better break free of past routines and innovate if they establish "breakout" [Downs 1967, 160] units or "entities separate from current operations" in order to "incubate new projects" [Teece 1998, 153], e.g., limited autonomy internal units such as "skunkworks" operations. ${ }^{25}$ A similar means can be used to combat premature convergence in neural networks.

Selection and retention overwhelm variation because positive feedback loops reinforce the first set of successful connections that emerge, tending to lock the pattern in. A set of neural networks performs best when, early in their training, communication between the networks is limited. Each network is given time to build its own interpretation before being exposed to the conclusions of others, so some solutions are allowed to emerge that do not initially seem as successful as others. [Anderson 1999, 123]

\footnotetext{
${ }^{22}$ Klein contrasts a marriage that works because the original marital bliss is maintained by unchanging attitudes and beliefs of the partners and no new challenges with a marriage that can constantly face and overcome new challenges with innovative solutions.

${ }^{23}$ Premature convergence (going too far along the wrong branch) is the "dual" error to the wasteful consideration of too many parallel options (too much branching away from the right branch).

${ }^{24}$ This echoes Schumpeter's point about "Creative Destruction" and the contrast between static and dynamic efficiency: "A system — any system, economic or other — that at every point of time fully utilizes its possibilities to the best advantage may yet in the long run be inferior to a system that does so at no given point of time, because the latter's failure to do so may be a condition for the level or speed of long-run performance." [Schumpeter 1962, 83] Along similar lines, Jacobs [1969] devotes a chapter to "The Valuable Inefficiencies and Impracticalities of Cities." ${ }^{25}$ See also Chapter 7: "Autonomy and Entrepreneurship" in Peters and Waterman 1982. The name "skunkworks" derives from Al Capp's L'il Abner comic strip where "Kickapoo joy juice" was brewed in a semi-isolated still with an occasional dead skunk thrown in for flavor.
} 
The shifting balance theory is also about the semi-isolation of parallel subpopulations that can develop their own "ideas" without being overwhelmed by the selective pressures of the main population. ${ }^{26}$ Philip Anderson goes on to note that this "insight helps explain why savvy managers often isolate innovation teams from the rest of the organization during the formative, exploratory learning period." [1999, 123]

The same basic idea is expressed by Burton Klein in his dynamic analysis of technology development decisions in contrast to the conventional "economizing" decisions to maximize the use of existing resources. "He... advocates looseness in goal-setting and gradual, oblique, or multiple approaches to the goal." [Hirschman and Lindblom 1971, 69] The goal is the breakthough to a dramatically better or more efficient alternative; not economizing every step of the way.

By having only a secondary interest in the static hill-climbing pressure for an "efficient combination of inputs," the development effort might cross a low-static-efficiency valley to a higher peak on the other side, i.e., find "radically improved performance characteristics." In a similar manner, the semi-isolation of Sewall Wright's subpopulations together with their greater variation might allow them to escape the current hill on the fitness landscape and to cross through a valley of reduced fitness to climb a higher peak elsewhere.

We now can use Wright's and Klein's ideas to summarize the relationship between biological and economic evolutionary dynamics.

\begin{tabular}{|l|l|l|}
\hline $\begin{array}{l}\text { Table 2: } \\
\text { Evolutionary } \\
\text { Dynamics }\end{array}$ & \multicolumn{1}{|c|}{ Biological } & \multicolumn{1}{c|}{ Economic } \\
\hline Rivalrous units & $\begin{array}{l}\text { Semi-isolated medium-sized } \\
\text { subpopulations or demes that can } \\
\text { interbreed. }\end{array}$ & $\begin{array}{l}\text { Medium-to-large firms that can } \\
\text { threaten each other's market share. }\end{array}$ \\
\hline $\begin{array}{l}\text { Semi-isolation from } \\
\text { competitive } \\
\text { pressures }\end{array}$ & $\begin{array}{l}\text { Allows greater variation in demes } \\
\text { reinforced through some } \\
\text { inbreeding. }\end{array}$ & $\begin{array}{l}\text { Allows experimentation and then } \\
\text { focused development within firms } \\
\text { to bring new products to market. }\end{array}$ \\
\hline $\begin{array}{l}\text { One way to stifle } \\
\text { innovation: hyper- }\end{array}$ & $\begin{array}{l}\text { Competition of individuals in one } \\
\text { large well-adapted population-any }\end{array}$ & $\begin{array}{l}\text { Pure competition of near-clones in a } \\
\text { well-defined market so any }\end{array}$ \\
\hline
\end{tabular}

\footnotetext{
${ }^{26}$ After a preliminary acquaintance with a new field of intellectual endeavor and its problems, suppose that an idea occurs to one about the problems. It is important to follow out the idea on one's own-deliberately refraining from reading what the experts have to say on the matter. Only later when one has acquired some footing of one's own through this active learning should one open up again and establish contact with the received wisdom in the field. By such a "naïve" and "wasteful" procedure (a self-imposed "skunkworks"), one can avoid getting stuck in the deep ruts cut by those who have gone before (premature convergence), ruts which might have prevented them from solving the problem. For an individual or organization already with formed views, the path to innovation may well lie in the "discrediting" [Weick 1979, 215] of "what we know." It was a recurring theme in the life of the physicist Richard Feynman to "disregard" [Gleick 1992, 387] the current literature except as a source of good problems that Feynman could then try to think through on his own.
} 


\begin{tabular}{|l|l|l|}
\hline $\begin{array}{l}\text { Table 2: } \\
\text { Evolutionary } \\
\text { Dynamics }\end{array}$ & \multicolumn{1}{|c|}{ Biological } & \multicolumn{1}{c|}{ Economic } \\
\hline competition & deviation is demise. & deviation spells failure. \\
\hline $\begin{array}{l}\text { Other way to stifle } \\
\text { innovation: lack of } \\
\text { competitive pressure }\end{array}$ & $\begin{array}{l}\text { Isolated population largely with } \\
\text { genes fixed by inbreeding rather } \\
\text { than by selective pressure. }\end{array}$ & $\begin{array}{l}\text { Uncontested monopoly with } \\
\text { "inbred" vested interest in } \\
\text { continuing the same product. }\end{array}$ \\
\hline $\begin{array}{l}\text { Transmission of } \\
\text { innovations between } \\
\text { rivalrous units }\end{array}$ & $\begin{array}{l}\text { Migration of superior genes } \\
\text { between demes. }\end{array}$ & $\begin{array}{l}\text { Transmission of superior ideas by } \\
\text { imitation, reinvention, or licensing. }\end{array}$ \\
\hline $\begin{array}{l}\text { Static efficiency } \\
\text { Dynamic efficiency }\end{array}$ & $\begin{array}{l}\text { Well-adapted to top of hill in } \\
\text { fitness landscape. }\end{array}$ & $\begin{array}{l}\text { Optimum so that local variations } \\
\text { are all downhill. }\end{array}$ \\
\hline $\begin{array}{l}\text { selection and variation for } \\
\text { continuous problem-solving and } \\
\text { improvement. }\end{array}$ & $\begin{array}{l}\text { Optimal mix of (static) efficiency } \\
\text { and innovation for continuous } \\
\text { problem-solving and improvement. }\end{array}$ \\
\hline $\begin{array}{l}\text { System to obtain } \\
\text { dynamic efficiency }\end{array}$ & $\begin{array}{l}\text { Shifting balance combination of } \\
\text { variation in demes for searching } \\
\text { other hills and migration for } \\
\text { transmitting successes. }\end{array}$ & $\begin{array}{l}\text { Schumpeterian rivalry between } \\
\text { profit-seeking firms creating } \\
\text { perennial gale of creative } \\
\text { destruction. }\end{array}$ \\
\hline
\end{tabular}

\section{Jane Jacobs' Vision of Development Through Volatile Inter-City Trade}

Although working well outside the confines of the "professional" study of economies know as "Economics", Jane Jacobs' voraciously eclectic work [1969; 1984] contributes to the tradition emphasizing the virtues of open-ended multiple approaches and the limitations of centralized urban planning.

She arrives at a parallel experimentation process between cities (as the demes) by focusing first on how old work leads to new diversified work within cities (variation within demes) and then on the volatile trade between cities (transmission of new genes). Each specialization of old work to achieve efficiency will soon lead to new work as the diversification of outputs into various product niches, to backward integration to produce previously imported inputs, and perhaps to unexpected 'matings' with nearby processes and products to produce novel offspring. This is the sort of innovation that tends to happen when diverse people with various skills and complementary knowledge jostle together in companies, and companies jostle together in cities. "This process in which one sort of work leads to another must have happened millions of times in the whole history of human economic development." [Jacobs 1969, 53]

Given these processes of old work leading to new work within cities, the cities can grow through a process of dynamic interaction with each other by direct or indirect rivalry. To play in the "game," a city must produce something which it can export-perhaps based on its natural endowment. That is its "message" and "challenge" to other cities. The export earnings can then

\footnotetext{
${ }^{27}$ See Aghion et al. 2002 for a specific model of these shifting balances.
} 
buy imports from other cities that were not produced in the given city. But if the other cities were not too advanced, then the import will present a plausible challenge to be replaced through learning and improvisation and perhaps improved upon within the city. Thus the products traded between cities are the "ideas" or "discoveries" transmitted from one city to another.

In the meantime, the other cities might be replacing the original exports of a city; its temporary advantage might be competed away. Now the domestic and perhaps improved version of the originally imported products can then be re-exported perhaps to the other cities that are less developed or have different specializations. The new export earnings will then purchase other more challenging imports, and the process can repeat itself ratcheted up at a higher level.

In this matter, a diversified group of innovative cities can through trade learn from each other and are ratcheting up or "developing on one another's shoulders." [Jacobs 1984, 144] This could well be called the "Jacobs' Ladder" mechanism for climbing toward the "Heaven" of development through volatile intercity trade.

Jacobs also develops her version of Hirschman's vision of the innovative developmental process of problem-solving leading to more problems and pressures which in turn calls forth more problem-solving and so on.

Earlier I defined economic development as a process of continually improvising in a context that makes injecting improvisations into everyday life feasible. We might amplify this by calling development an improvisational drift into unprecedented kinds of work that carry unprecedented problems, then drifting into improvised solutions, which carry further unprecedented work carrying unprecedented problems... [Jacobs 1984, 221-2]

Instead of a vision of integrated rational planning based on a comprehensive overview (series experimentation), Jacobs and Hirschman as well as Lindblom and Klein all envisage a process driven by endogenous pressures that call forth innovative problem-solving from multiple agents which, in turn, creates beneficial cross-learning and rivalrous counter-strategies-moves and countermoves_-ratcheting forward through seesaw advances.

\section{Donald Schön and Everett Rogers on Decentralized Social Learning}

The default theory of social learning is that the center makes policy innovations-series experimentation — which are then transmitted to the periphery.

Central attempts to 'train' agencies at the periphery. In spite of the language of experimentation, government-initiated learning tends to be confined to efforts to induce localities to behave in conformity with central policy. [Schön, 1971, 177]

But social learning can take place in a decentralized bottom-up manner with centralized coordination. In large multi-plant companies, innovation may take the form of new ways of socially organizing and structuring productive processes, e.g., quality circles or self-managed work teams. Separate plants might perform pilot experiments to find out "what works and what doesn't." The headquarters office frames the experiments, detects the successes, and plays the 
knowledge-broker to help other plants cross-learn from the successful ones. In the Japanese system of just-in-time inventories, there is local problem-solving by teams, benchmarking between teams, and continuous improvement ratcheting up the performance of the teams. ${ }^{28}$

Schön described a similar process involving the government and the periphery of local units trying to carry out a certain social reform.

The opportunity for learning is primarily in discovered systems at the periphery, not in the nexus of official policies at the center. Central's role is to detect significant shifts at the periphery, to pay explicit attention to the emergence of ideas in good currency, and to derive themes of policy by induction.... Central comes to function as facilitator of society's learning, rather than as society's trainer. [Schön, 1971, 177-8]

Decentralized parallel experimentation with centrally-sponsored framing and benchmarking followed by peer-to-peer cross-learning in the periphery (like deme-to-deme cross-learning in Wright's theory) is a more appropriate model than research at a central facility followed by the teaching-dissemination of the results.

In Everett Rogers' early work on the diffusion of innovations he focused on the classical huband-spokes or center-periphery model of diffusion. Spurred on by Schön's work [1971], he became aware of decentralized diffusion systems with horizontal diffusion between peers (which might involve partial re-invention of the model) rather than vertical transmission from experts to adopters.

Instead of coming out of formal R\&D systems, innovations often bubbled up from the operational levels of a system, with the inventing done by certain users. Then the new ideas spread horizontally via peer networks, with a high degree of reinvention occurring as the innovations are modified by users to fit their particular conditions. ...

Gradually, I began to realize that the centralized diffusion model was not the only wheel in town. [Rogers 1983, 334]

Perhaps the best example of a parallel system of decentralized innovation and diffusion in a developing country is in China over the last quarter of a century. The Chinese recognized local reform models which could be in a region, county, commune, or even brigade, and could be in any sector or area such as administration, health, education, or industry. The center would recognize a "model" which could then be visited by groups from all over China who want to make a similar reform in their locality. The same period marks the beginning of China's historic record of growth and development at the end of the twentieth century.

\section{Charles Sabel's Vision of Social Learning by Parallel Experimentation}

The Japanese system of just-in-time inventories, local problem-solving by teams, benchmarking between teams, and continuous improvement can also be seen as a system of systematic learning

\footnotetext{
${ }^{28}$ This example with the parallel experimentation of teams plays a major role in Charles Sabel's theory of learning by monitoring [1994]. See later quote from Sabel and Reddy.
} 
in production that induces decision-making, problem-solving, and ownership by the participants. Charles Sabel has made the most sustained development of these and other examples of social learning in parallel experimentation schemes in his theory of learning by monitoring [1994] and in much other work on social learning and the ratcheting up of performance standards in decentralized regulatory arrangements [Sabel et al. 2000]. ${ }^{29}$

Often development strategies are flawed by implicitly assuming that which needs to be created. This often takes the form of assuming an effective governance system is in place so that a development advisor simply has to pour some new wine into the sound bottle, e.g., design a comprehensive set of conditionalities to be implemented by a developing country. In large organizations, top managers often adopt new strategic plans as if the problems lay in the specifics of the plan rather than in the lack of capacity to implement management's writ. The implicit assumption of an effective governance system imputes to the government of a country or to the management of a company a capacity to resolve coordination and collective action problems by command and control. Sabel, like Albert Hirschman before him, asks how collective action problems are solved in the small and how change does take place-without assuming an effective fiat from the center. By developing a more realistic theory of change, they can then "back out" a more reasonable description of what the center could do to catalyze, assist, broker, and guide the process-rather than trying to finesse the problem by assuming ab initio that the center can effectively implement its plans.

Sabel's treatment of collective action problems through learning by monitoring is particularly fruitful by showing important ways in which trust and "social capital" are developed without falling back on the conventional banalities about cultural inheritance and education. Individuals are assumed to have some sociability, some powers of reflection and discussion, and incomplete identities always in the process of formation and change. They are often in problematic situations where some cooperative action would benefit the group but where each may be vulnerable to the non-cooperation of others (which could be defection or simply error). The problem being discussed is not a problem involving others in some distant place; it is the group members' own common problem so that they would be involved in implementing any proposed solution (the "learning") and will thereby be monitoring the actions of others-and hence the description "learning by monitoring." The discussion to arrive at a collective action plan must also include discussion of how to apportion the gains from cooperation and how to adjudicate differences that will arise.

So far the description of learning by monitoring does not differ substantially from the repeated games treatment of the evolution of "cooperation" [e.g., Axelrod 1984]. Sabel goes beyond the game-theoretic treatment by assuming that the self-definitions and identities of the participants are changed by the discussion and cooperative efforts. Part of the discussion is to reinterpret and reframe their past, to discover and clarify their interests, and to establish a group identity with which the members can start to identify so that the cooperation is based more and more on "who they are" than on a tenuous game-theoretic modus vivendi (cooperating today only to avoid punishment tomorrow). The reciprocal belief that others also cooperate partly on the basis of identification (rather than strategy and guile) will lead to giving others some "benefit of the

${ }^{29}$ See: http://www2.law.columbia.edu/sabel/papers.htm 
doubt" by interpreting occasional non-cooperation by members as error rather than betrayal. In such a manner, trust and the norms of reciprocity (social capital) can be developed.

Central managers or coordinators, instead of being assumed as a deus ex machina, can be seen as agents of the group facilitating the "government by discussion" within the group and helping to minimize the vulnerabilities of cooperative action-while through benchmarking and other means of competitive stimulus helping to insure that the group continues to face the problems that come to light.

Where a set of people have interdependent opportunities and fates, the group members through initial problem-solving discussion and action accompanied by mutual monitoring can start to bootstrap a new collective identity that can help to stabilize future cooperative problem-solving and learning. Overall, this is a species of pragmatism which John Dewey saw as being exemplified in scientific communities and democratic polities.

Learning by monitoring is in this sense an institutional device for turning, amidst the flux of economic life, the pragmatic trick of simultaneously defining a collective-action problem and a collective actor with a natural interest in addressing it. The disequilibria created by learning by monitoring are informatively effective for the same reasons as scientific experiments and democratic rule; and under these conditions the differences between the disciplines of the factory and the laboratory dwindle in the face of their similarities. [Sabel 1994, 272]

\section{Parallel Experimentation in Development}

The basic idea of parallel experimentation applied to social learning is that when a central agency does not know the answer (almost always the case in questions of development), then its best strategy is to sponsor a program of parallel decentralized experiments with discussion, benchmarking, and horizontal learning between the experimenters_all of which will tend to ratchet up the performance of the whole group.

Recently, Charles Sabel and Sanjay Reddy have proposed just such a mechanism of parallel experimentation for social learning for development.

At the "top" a benchmarking committee of the relevant government entities and qualified private actors, collaborates with potential users to establish the initial substantive and procedural criteria for participation, and defines the initial metrics by which applications are to be ranked. At the "bottom" project groups-whose members can be public or private entities or partnerships of both-compete to present projects that score highly under the emergent criteria....After each round the selection criteria, benchmarks and institutional arrangements are adjusted to reflect improved measures of performance and a richer understanding of success. [Sabel and Reddy 2003, 10] 
Start with a persistent social problem in a developing or transitional country, e.g., how to do bankruptcies and industrial restructuring, how to promote small private firms in a corrupt environment, how to fight endemic corruption, how to provide public services, and so forth. The agency (e.g., some appropriately local development agency) proposes a competition (e.g., between national regions, states, cities, etc.) for the best approach to addressing the problem. To qualify, an entrant must make public the "theory" or ideas behind their approach. Moreover, they must agree to be judged by certain public benchmarking criteria (which they might themselves propose).

Based on the proposals, some of which could describe already existing programs, the agency will select a certain number of winners and will provide material assistance in some form, e.g., a block grant. The assistance will always require a substantial matching contribution (which could be as prior investment) from the entrants to assure that they want to solve the problem and are not just in it to get the assistance. In any case, the aid provided by the agency is the least important part of the parallel experimentation scheme. The more the aid, the more a central agency will be emboldened to start dictating "answers" so the aid should be unobtrusively small so as not to interfere with the primary motivation of the public hunt for solutions to address a pressing problem.

The others in the contest will learn the winning theories as to how the problem can be addressed and they may choose to adapt their own mode of operation. After a certain time period, the results are assessed according to the previously agreed-upon benchmarks to see who the real winners were. There might be a second round of assistance where aid would go to those who did well in the first round (whether they previously received assistance or not). The point is to encourage horizontal or cross-learning between those who did well and those who didn't. Project funds might also be used to sponsor visits or secondments so that the laggards could learn directly from the emerging success stories. The public benchmarking establishes a rolling standard that will ratchet up as social learning improves performance (continuous improvement). Matters of local pride and prestige will play a role.

The public benchmarking between parallel experiments and ratcheting up of standards of performance are the heart of a real-time notion of parallel evaluation that stands in sharp contrast to the traditional notion of evaluation. Conventionally, the experts decide on the One Best Way which was supposed to be implemented. Then after a number of years, an evaluation is performed to learn from the results. Leaving aside all the enormous problems in the objectivity of evaluations and the resistance of bureaucracies to learning (due to the implication of prior error), the idea is that experts will take the "learnings" to heart to give still better redesigned recommendations the next time. But under conditions of uncertainty and acknowledged ignorance (not knowing the One Best Way), the best approach seems to be parallel experimentation and the real-time evaluation of benchmarking and communication of ideas between the experiments.

\section{Conclusions}

Evolutionary dynamic processes in any field will operate through the interaction of two forces or moments, variation and selection. Variation expands the range of options while selection narrows the options. Evolutionary theories in biology, economics, and many other fields have 
focused on the selection mechanism and have paid much less attention to variation. Yet on a rugged and cloudy "fitness landscape," selection without variation would tend to be stuck on a low hill. Some process of variation is necessary to move downhill against selectionist pressures to cross a valley of low fitness and then climb a higher peak. By abstracting from instances in several fields, particularly Sewall Wright's shifting balance theory of evolution, we have arrived at a general scheme of parallel experimentation as the variational moment in dynamic evolutionary processes:

- different experiments running concurrently with some common goal (rather than focusing resources on what currently seems like the best option),

- with some semi-isolation from the pressure of immediate success,

- with benchmarking comparisons made between the experiments, and

- with the "migration" of discoveries between experiments wherever possible to ratchet up the performance of the whole population.

The parallel experimentation scheme suggests a certain correspondence between biological and economic evolution. Instead of mapping the individual firm in a purely competitive model to the individual organism involved in the survival of the fittest, the medium-to-large firms in a Schumpeterian rivalrous market should be mapped to the demes or subpopulations in Wright's shifting balance theory. In both cases, it is a shifting balance of selectional and variational processes that yields the dynamic efficiency of continuous problem-solving and improvement. By seeing the same sort of parallel experimentation scheme in a variety of different fields, we bolster our confidence that it is important to the dynamics of development.

\section{References}

Aghion, P., N. Bloom, R.Blundell, R. Griffith, and P. Howitt, 2002. Competition and Innovation: An Inverted U Relationship. Institute for Fiscal Studies Working Paper WP02/04: 60.

Anderson, Philip 1999. Seven Levers for Guiding the Evolving Enterprise. In The Biology of Business. Ed. by J. H. Clippinger. San Francisco: Jossey-Bass: 113-52.

Axelrod, Robert 1984. The Evolution of Cooperation. New York: Basic Books.

Axelrod, Robert and Michael Cohen 1999. Harnessing Complexity: Organizational Implications of a Scientific Frontier. New York: Free Press.

Burckhardt, Jacob 1998 (1898). The Greeks and Greek Civilization. New York: St. Martin's Griffin.

Burnet, Macfarlane 1959. The Clonal Selection Theory of Acquired Immunity. Cambridge: Cambridge University Press.

Campbell, Donald T. 1974. Evolutionary Epistemology. In The Philosophy of Karl Popper Vol. I. Ed. by P. A. Schilpp. La Salle IL: Open Court Publishing: 413-63.

Chang, Ha-Joon, Ed. 2001. Joseph Stiglitz and the World Bank: The Rebel Within. London: Anthem.

Cziko, Gary 1995. Without miracles: Universal selection theory and the second Darwinian revolution. Cambridge: MIT Press (A Bradford Book). 
David, Paul 1985. Clio and the Economics of QWERTY. American Economic Review. 75 (2 May): 332-7.

David, Paul and Dominique Foray 1994. Dynamics of Competitive Technology Diffusion Through Local Network Structures: The Case of EDI Document Standards. In Evolutionary Economics and Chaos Theory. Ed. by L. Leydesdorff and P. Van den Besselaar. New York: St. Martin's Press: 63-78.

Dawkins, Richard 1983. Universal Darwinism. In Evolution from molecules to man. D. S. Bendall ed., Cambridge UK: Cambridge University Press: 403-425.

Dawkins, Richard 1996. Climbing Mount Improbable. New York: W. W. Norton \& Company.

De Grazia, Alfred 1975. Eight Bads--Eight Goods: The American Contradictions. Garden City: Anchor Books.

Dennett, Daniel 1995. Darwin's Dangerous Idea: Evolution and the Meanings of Life. New York: Touchstone.

Dewey, John 1939. Freedom and Culture. New York: Capricorn.

Downs, Anthony 1967. Inside Bureaucracy. Boston: Little, Brown.

Edelman, Gerald 1987. Neural Darwinism: The theory of neuronal group selection. New York: Basic Books.

Eigen, Manfred 1992. Steps Towards Life. Oxford: Oxford University Press.

Ellerman, David 1988. The Legitimate Opposition at Work: The Union's Role in Large Democratic Firms. Economic and Industrial Democracy: An International Journal. 9(4 Nov,): 437-53.

Ellerman, David 1995. Intellectual Trespassing as a Way of Life: Essays in Philosophy, Economics, and Mathematics. Lanham MD: Rowman \& Littlefield.

Ellerman, David 2002. Should development agencies have Official Views? Development in Practice. 12(3): 285-97.

Fodor, Jerry and Massimo Piattelli-Palmarini 2010. What Darwin Got Wrong. New York: Farrar, Straus and Giroux.

Gleick, James 1992. Genius: The Life and Science of Richard Feynman. New York, Vintage.

Haas, Ernst B. 1990. When Knowledge is Power: Three Models of Change in International Organizations. Berkeley: University of California.

Hayek, Friedrich 1984. The Essence of Hayek. Stanford CA: Hoover Institution Press.

Hayek, Friedrich 1988. The Fatal Conceit. W. W. Bartley III (ed.) Chicago: University of Chicago Press.

Hirschman, Albert O. 1958. The Strategy of Economic Development. New Haven: Yale University Press.

Hirschman, Albert O. 1970. Exit, Voice, and Loyalty: Responses to Decline in Firms, Organizations, and States. Cambridge: Harvard University Press.

Hirschman, Albert O. 1973. Journeys Toward Progress. New York: Norton.

Hirschman, Albert O. and Charles E. Lindblom 1971 (orig. 1962). Economic Development, Research and Development, and Policy Making: Some Converging Views. In A Bias for Hope. New Haven: Yale University Press: 63-84. 
Hodgson, Geoffrey M. 1996. Economics and Evolution: Bringing Life Back into Economics. Ann Arbor: University of Michigan.

Jacobs, Jane 1969. The Economy of Cities. New York: Random House.

Jacobs, Jane 1984. Cities and the Wealth of Nations: Principles of Economic Life. New York: Random House.

Janis, Irving L. 1972. Victims of Groupthink. Boston: Houghton Mifflin.

Jerne, Niels K. 1955. The natural selection theory of antibody formation. Proc. National Academy of Sciences U.S.A. 41: 849.

Kanigel, Robert 1997. The One Best Way: Frederick Winslow Taylor and the Enigma of Efficiency. New York: Viking.

Keynes, John Maynard 1936. The General Theory of Employment, Interest, and Money. New York: Harcourt, Brace \& World.

Kirschner, Marc W. and John C. Gerhart 2005. The Plausibility of Life: Resolving Darwin's Dilemma. New Haven: Yale University Press.

Klein, Burton H. and William Meckling 1958. Application of operations research to development decisions. Operations Research. 6: 352-63.

Klein, Burton H. 1977. Dynamic Economics. Cambridge MA: Harvard University Press.

Klein, Burton H. 1984. Prices, Wages and Business Cycles: a dynamic theory. New York: Pergamon Press.

Knight, Frank 1965 (1921). Risk, Uncertainty and Profit. New York: Harper Torchbooks.

Lindblom, Charles 1965. The Intelligence of Democracy: Decision Making Through Mutual Adjustment. New York: Free Press.

Lindblom, Charles 1990. Inquiry and Change. New Haven: Yale University Press.

Lipset, Seymour, Martin Trow and James Coleman 1962. Union Democracy. Garden City: Anchor Books.

Lloyd, G.E.R. 1996. Adversaries and Authorities: Investigations into ancient Greek and Chinese science. Cambridge UK: Cambridge University Press.

Matson, Floyd 1966. The Broken Image: Man, Science and Society. Garden City NY: Anchor Books.

Metcalfe, J.S. 2001. Technology and Economic Development: A Comparative Perspective (Background paper for the World Industrial Development Report UNIDO 2001). Manchester UK, Centre for Research on Innovation and Competition: 42 pages.

Mill, John Stuart 1972. On Liberty. In J.S. Mill: Utilitarianism, On Liberty and Considerations on Representative Government. Ed. by H. B. Acton. London: J.M. Dent \& Sons.

Mokyr, Joel 1990. The Lever of Riches: Technological Creativity and Economic Progress. New York: Oxford.

Needham, Joseph 1969. The Grand Titration. Toronto: University of Toronto Press.

Nelson, Richard R. 1961. Uncertainty, Learning and the Economics of Parallel Research and Development Efforts. Review of Economics and Statistics. 43(November), 351-64.

Nelson, Richard R. 1995. Recent Evolutionary Theorizing About Economic Change. Journal of Economic Literature. 33(1): 48-90. 
Nelson, Richard and Sidney Winter 1982. An Evolutionary Theory of Economic Change. Cambridge: Harvard University Press.

Peters, Thomas J. and Robert H. Waterman 1982. In Search of Excellence. New York: Warner Books.

Polanyi, Michael 1951. The Logic of Liberty. Chicago: University of Chicago Press.

Polanyi, Michael 1966. The Tacit Dimension. Garden City NY: Doubleday.

Popper, Karl 1965. Conjectures and Refutations: The Growth of Scientific Knowledge. New York: Harper \& Row.

Popper, Karl R 1979. Objective Knowledge: An Evolutionary Approach. Oxford: Clarendon Press.

Provine, William B. 1971. The Origins of Theoretical Population Genetics. Chicago: Chicago University Press.

Provine, William B. 1986. Sewall Wright and Evolutionary Biology. Chicago: University of Chicago Press.

Raymond, Eric S. 1998. The Cathedral and the Bazaar. http://firstmonday.org/issues/issue3_3/raymond/index.html

Rogers, Everett 1983. Diffusion of Innovations. $3^{\text {rd }}$ edition. New York: Free Press.

Rohr, Janelle, Ed. 1989. The Third World: Opposing Viewpoints. San Diego CA: Greenhaven Press.

Rosenberg, Nathan and L.E. Birdzell 1986. How the West Grew Rich: The Economic Transformation of the Industrial World. New York: Basic Books.

Sabel, Charles 1994. Learning by Monitoring: The Institutions of Economic Development. In Rethinking the Development Experience: Essays Provoked by the Work of Albert $O$. Hirschman. Ed. by L. Rodwin and D. Schön. Washington: Brookings Institution: 231-274.

Sabel, Charles, Archon Fung and Bradley Karkkainen 2000. Beyond Backyard Environmentalism. Boston: Beacon Press.

Sabel, Charles and Sanjay Reddy 2003. Learning to Learn: Undoing the Gordian Knot of Development Today. Columbia Law and Economics Working Paper No. 308. http://www2.law.columbia.edu/sabel/papers.htm

Sagan, Carl 1996. The demon-haunted world: Science as a candle in the dark. New York: Random House.

Sah, Raaj and Joseph Stiglitz 1985. Human Fallibility and Economic Organization. American Economic Review. 75(2 May): 292-7.

Schön, Donald 1971. Beyond the Stable State. New York: Norton.

Schön, Donald 1983. The Reflective Practitioner. New York: Basic Books.

Schumpeter, Joseph 1934. The Theory of Economic Development: An Inquiry into Profits, Capital, Credit, Interest, and the Business Cycle. Trans. Redvers Opie, Cambridge Mass: Harvard University Press. (Originally published in German in 1912 as Theorie der wirtschaftlichen Entwicklung.)

Schumpeter, Joseph A. 1962. Capitalism, Socialism and Democracy. New York: Harper Torchbooks. 
Schwenk, C.R. 1984. Devil's Advocacy in Managerial Decision Making. Journal of Management Studies(April): 153-68.

Schwenk, C. 1989. A Meta-Analysis of the Comparative Effectiveness of Devil's Advocacy and Dialectical Inquiry. Strategic Management Journal. 10(3): 303-6.

Shackle, G. L. S. 1992. Epistemics and Economics. New Brunswick: Transaction Publishers.

Smith, Jeffery A. 1988. Printers and Press Freedom: The Ideology of Early American Journalism. New York: Oxford University Press.

Stiglitz, Joseph 1994. Whither Socialism? Cambridge MA: MIT Press.

Stiglitz, Joseph 2002. Globalization and Its Discontents. New York: Norton.

Strang, Gilbert 1986. Introduction to Applied Mathematics. Wellesley MA: WellesleyCambridge Press.

Sunstein, Cass 2003. Why Societies Need Dissent. Cambridge: Harvard University Press.

Tanese, Reiko 1989. Distributed genetic algorithms. Proc. 3rd International Conference on Genetic Algorithms, 434-39.

Tawney, Richard H. 1954. Religion and the Rise of Capitalism. New York: Mentor Books.

Teece, David 1998. Design Issues for Innovative Firms: Bureaucracy, Incentives and Industrial Structure. In The Dynamic Firm: The Role of Technology, Strategy, Organization, and Regions. Ed. by A. Chandler, P. Hagström and Ö. Sölvell. Oxford: Oxford University Press: 134-65.

Thompson, W. R. 1933. On the Likelihood That One Unknown Problem Exceeds Another in View of the Evidence of Two Samples. Biometrika. 25: 275-94.

Veblen, Thorstein 1919. The Place of Science in Modern Civilization and Other Essays. New York: Huebsch. Reprinted 1990 with a new introduction by W. J. Samuels. New Brunswick: Transaction.

Von Alven, William, Ed. 1964. Reliability Engineering. Englewood Cliffs: Prentice-Hall.

Wallace, Robert, Gerald Sanders and Robert Ferl 1991. Biology: The Science of Life. New York: HarperCollins.

Weick, Karl 1979. The Social Psychology of Organizing. New York: Random House.

Wills, Garry 1994. Certain Trumpets: The Call of Leaders. New York: Simon \& Schuster.

Witt, Ulrich 2006. Evolutionary concepts in economics and biology. Journal of Evolutionary Economics. 16: 473-476.

Wright, Sewall 1932. The Roles of Mutation, Inbreeding, Crossbreeding, and Selection in Evolution. Proceedings of the Sixth International Congress of Genetics. 1: 356-66. Reprinted in: Wright 1986, 161-71.

Wright, Sewall 1986. Evolution: Selected Papers. Chicago: University of Chicago Press. Young, Allyn 1928. Increasing Returns and Economic Progress. Economic Journal. 38 (December): 527-42. 